\title{
Higher Education as a Bridge between China and Nepal: Mapping Education as Soft Power in Chinese Foreign Policy
}

\author{
Priya Gauttam ${ }^{1}$, Bawa Singh ${ }^{1}$ and Vijay Kumar Chattu ${ }^{2,3,4, * \text { (D) }}$ \\ 1 Department of South and Central Asian Studies, School of International Studies, Central University of Punjab, \\ Bathinda 151401, India; arch.priyagautam1996@gmail.com (P.G.); bawasingh73@gmail.com (B.S.) \\ 2 Department of Medicine, Temerty Faculty of Medicine, University of Toronto, Toronto, ON M5G 2C4, Canada \\ 3 Institute of International Relations, The University of the West Indies, \\ St. Augustine, Trinidad and Tobago \\ 4 Department of Public Health, Saveetha Institute of Medical and Technical Sciences, Saveetha University, \\ Chennai 600077, India \\ * Correspondence: vijay.chattu@mail.utoronto.ca; Tel.: +1-(416)-864-6060
}

Citation: Gauttam, P.; Singh, B.; Chattu, V.K. Higher Education as a Bridge between China and Nepal: Mapping Education as Soft Power in Chinese Foreign Policy. Societies 2021, 11, 81. https://doi.org/10.3390/ soc 11030081

Academic Editor: Gregor Wolbring

Received: 28 June 2021

Accepted: 10 July 2021

Published: 15 July 2021

Publisher's Note: MDPI stays neutral with regard to jurisdictional claims in published maps and institutional affiliations.

Copyright: (c) 2021 by the authors. Licensee MDPI, Basel, Switzerland. This article is an open access article distributed under the terms and conditions of the Creative Commons Attribution (CC BY) license (https:// creativecommons.org/licenses/by/ $4.0 /)$.

\begin{abstract}
In this globalized world, education has become an important medium to enhance peopleto-people contact. The Delores report of the International Commission on Education for the 21st century highlights the enormous potential of higher education to use globalization as a resource for bridging the knowledge gap and enriching cross-cultural dialogue. As a major contributor to soft power and an important field of public diplomacy, international education can have a wealth of advantages, including the ability to generate commercial value, promote a country's foreign policy goals and interests, and contribute to economic growth and investment. The People's Republic of China, well-known for being the world's most populous nation and the global economic powerhouse, prioritizes the internationalization of the country's higher education system. China is looking to expand its higher education program and carry out its diplomatic project in South Asia. In this sense, the South Asian zone, especially Nepal, is significant for China, where its educational diplomacy is playing as a "bridge between Sino- Nepal relations." In this review, we describe the place and priority of "Education" in China's foreign policy; explore China's mediums of investment in Nepal's education sector; and highlight the importance of educational aid in Sino-Nepal relations. Chinese educational aid to Nepal takes many forms, where Nepali students and officials engage with Chinese investment to enhance their career prospects and the education system in Nepal.
\end{abstract}

Keywords: education; Sino-Nepal relations; public diplomacy; soft power; educational aid; investment; Asian societies; Belt and Road Initiative (BRI); geopolitical

\section{Introduction}

Fudan University (China) alumnus Dr. Kalyan Raj Sharma, from Nepal, was awarded the Silk Road Friendship Award (2020). This award was given by China International Cultural Exchange Center and Global People magazine. Recipients were chosen from a pool of more than 100 candidates in agriculture, industry, shipping, business, education, art, health and other sectors [1]. Dr. Sharma is a visiting lecturer at Kathmandu University and the President of Nepal AOE Tourism Company. In 2013, he established the Nepal China Friendship Forum (NCFF) after returning to Nepal from China. The forum brings the governments, diplomats, academia, corporate sector, media, other relevant organizations and individuals on one platform to provide opportunities for the academic exchange in fields such as Chinese and Nepalese literature, medicine, social work and other related subjects. Since 2015, every year the NCFF has hosted a series of BRI Conferences to discuss the benefits of BRI for Nepal and South Asian countries, which has received widespread attention from both nations, and has been covered by mainstream media on the part of both the countries. As a regular visiting professor at Kathmandu University School of 
Management, Sharma has presented China's growth experience with Nepalese students. Apart from this, he has been actively engaged in promoting Chinese culture and language among Nepalese students by organizing an excursion to China and enabling them to get first-hand experiences with the Chinese language and culture [1].

Furthermore, many private schools in Nepal have made it mandatory for Nepalese students to learn the Mandarin language. This move comes following a proposal by the Chinese government to subsidize the salary of Mandarian teachers in Nepali schools [2]. The above-mentioned case shows the reciprocated response of students who have studied in China, while the other shows the favorable investment of China in Nepal's education sector that helps it woo schools in Nepal. These are just two cases to understand the success of China's educational diplomacy, and many more such cases exist.

Although China and Nepal established diplomatic ties on 1 August 1955, both countries have been enjoying a long history of cultural, education, economic and trade exchanges and engagements, dating back to the Licchavi (around 400 to 750 A.D.) in Nepal and the Tang dynasty in China (618 to 907 A.D.). In contemporary times, the bilateral relations of both countries are largely guided by the Treaty of Peace and Friendship signed back in 1960. Since then, China has been providing aid to Nepal in various sectors such as economic, infrastructure development, military assistance, diplomatic exchanges and cultural and educational initiatives. China had overtaken India as Nepal's biggest Foreign Direct Investment source since 2014. The trade relations between the two countries have grown significantly after Nepal joined China's Belt and Road Initiative (BRI) project, a massive infrastructure project led by Beijing that includes the building and upgrading of transportation and commercial links. In the 2015-2016 and 2016-2017 fiscal year, China had invested US\$ $57 \mathrm{mn}$ and US\$ $76 \mathrm{mn}$, respectively, in the form of FDI in Nepal. In the fiscal year 2017-2018, Nepal had received China's pledge of US\$ 427 million, marking a significant increase in investment after Nepal joined the BRI project [3]. However, this pace slowed down in the 2018-2019 and 2019-2020 fiscal year, when China had pledged US\$ 116 million and US\$ 220 million FDI respectively in Nepal [4]. When Chinese President Xi Jinping visited Nepal in 2019 , he pledged nearly US $\$ 500$ million ( $€ 436.9$ million) as financial aid to Kathmandu [5]. Such increasing geopolitical and geostrategic clouts of China in Nepal have raised geopolitical concerns for India amidst the challenges and tensions over the boundary dispute. In contrast, these developments in Sino-Nepal cooperation are helping Kathmandu to achieve its economic interests with its powerful neighbor.

Ever since China had reformed and opened up its economy and adopted a policy of internationalization of higher education, its influence has been reflected in China's foreign policy. The priority of education in China's foreign policy is now helping Beijing increase its soft power and public diplomacy by disseminating its cultural values. Similarly, in Sino-Nepal relations, this cultural shift also suggests the significant geopolitical transformation and Beijing's increasing educational role in Nepal. Beijing's investment in Nepal's education sector opened up a new chapter in their bilateral relations. Importantly, this shift reflects Kathmandu's growing ties with Beijing, drifting away from Delhi, and a strategic reorientation towards the north. With regards to this, the objectives of this paper are-firstly, to examine the role of education in China's foreign policy discourse to provide the conceptual framework of the paper; secondly, to explore China's investment in Nepal in the field of education; and thirdly, to analyze the trajectory of higher education acting as a bridge between the two countries.

\section{Materials and Methods}

In this narrative review, data was collected from secondary sources from the published articles (peer-reviewed) and the relevant government websites and reports of Nepal and China. The databases used for the search included Web of Science, Scopus, Jstor and Google Scholar search engines to gather relevant information in the context of Sino-Nepal educational cooperation. As mentioned, the relevant data is mainly collected from the official websites of the Chinese Ministry of Education, the Chinese embassy in Nepal, the 
Ministry of Foreign Affairs of Nepal and China, joint statements of high-level official visits and the information published in newspapers. The famous newspapers included China's GlobalTimes, Xinhuanet, Kathmandupost, The Guardian Post, Deccan Herald and Times of India, which have reported on the topic of interest. After removing the duplicates, the review included around 74 sources, including peer-reviewed research articles, websites of ministries of education, foreign affairs and newspapers from China, Nepal and India. Based on these authentic sources, an exploratory and analytical approach has been used to explore various mediums of educational aid provided by China to Nepal and analyzed its contribution in providing various career opportunities to Nepali students. Before discussing Chinese investment in Nepal, it is important to understand the emergence and existence of education as a soft power and public diplomacy tool in China's foreign policy. The main findings from the literature search are described in the subsections of the results discussed below.

\section{Results}

The main results from the literature review are summarized in the subsections below. The key identified areas are Sino-Nepalese cultural cooperation, Education in China's Foreign Policy Discourse and Nepal's geopolitical significance for China.

\subsection{Sino-Nepalese Cultural Cooperation}

As a landlocked country between India and China, Nepal wants to take advantage of its significant geopolitical location. For a couple of decades, Nepal's economic engagements with the outside world have relied on the Indian ports, with two-thirds of all products entering and leaving the country traveling via the latter. With the signing of the Trade and Transit Agreement with China in 2016, Nepal has been seeking to break its complete dependence on India, as this treaty had provided Nepal access to seven Chinese sea and land ports [6]. China is the emerging superpower of the world. With its huge economic and military power, China has the potential to claim superpower status [7-10]. Hence, Kathmandu does not want to lose the chance of maximizing the benefit from its most powerful neighbor.

On the other hand, India-Nepal relations have been experienced during the regime of the incumbent Indian government, especially in the economic blockade of 2015 [11]. The recent conflicts between India-Nepal over the Kalapani area and Nepal's re-issuance of its political map by incorporating the three Indian areas have actually damaged their bilateral relations to a great extent [12]. Still, the one positive aspect of Indo-Nepal relations is its cultural, religious and people-to-people contacts. Nepal shares an open border with India, and their closeness is widely recognized as a "bread and daughter relationship, representing family ties among people of both countries. On the contrary, the bilateral engagements between Nepal and China have been growing exponentially. Economically, China has already surpassed India [13], and is consistently making efforts to heighten multi-dimensional relations with Nepal, in general, cultural and education in particular.

In a bid to enhance people-to-people contacts between China and Nepal, educational diplomacy has been figuring very prominently in Chinese foreign policy. After the economic reforms period, the realm of higher education systematically planned soft power had been one of the most important the focus and pursuit of China's foreign policy. Ever since China had signed MoUs with Nepal on Cultural Cooperation (1999) and Youth Exchange (2009), both countries have been exchanging youth for scholarships/fellowships provided by the Chinese Government. As of 2018, more than 6400 Nepali students had received scholarships from the Chinese government to study in Chinese universities. Moreover, around 160 Nepali students have studied in Chinese universities for the 2018-2019 academic years under the government of China's scholarship program [14].

Additionally, Beijing has been organizing various exhibitions to woo Nepalese students and establish several educational institutions to enhance people-to-people contacts. Reflecting a large pattern of Chinese investment in Nepal, the education sector hosts a 
series of complementary projects being developed in partnership with the Chinese government. China has now emerged as a top education destination for the younger generation of Nepal, which is serving as a bridge between China and Nepal for cordial relations.

\subsection{Education in China's Foreign Policy Discourse}

Foreign policy has been examined as the interactions between diverse political agents (including individuals with specific needs) and the structures established by social relationships (such as the state, as well as organizations and rules which are commonly constructed [15]. In the case of China, as the country's international interests and responsibilities have been growing exponentially, both individuals and groups, and particularly organizations within it, are getting involved in its foreign affairs. The emergence of China within the international system was one of the most significant changes in global relations at the turn of the 21st century. So much has been discussed and written about China's development in power during the last half-century, which has been referred to as a "rise" or "emergence" from an isolated state to a regional power to a potential great power capable of exerting significant influence not just in the Asian region, but also at the global level. Assuming Chinese power continues to increase in the short term, comprehending the country's quick shifts in foreign policy has become more important than ever. This success may be analyzed in a range of international relations domains, ranging from diplomacy to security, economy to culture and the environment, all of which raises the question of which foreign policy the country will pursue, as it consolidates its position as a great power.

China has a wealth of culture and history. China's influence on the world is gradually increasing. Kurlantzick [16] and Nye [17] have observed the rise of China and the growing number of people turning to know more about the country: "China has always had an attractive traditional culture, but now it is entering the realm of global popular culture as well. The enrolment of foreign students in China has tripled to 110,000 from 36,000 over the past decade, and the number of foreign tourists has also increased dramatically to 17 million last year ... it would be foolish to ignore the gains it is making" [17]. China's success in the market in recent years draws the world's attention towards this nation, which is located in the far eastern part of Asia. Since the opening of the economy, "Made in China" products have made their way to almost every corner of the world. People around the world are now more interested in learning about China's success story and the source behind the "Made in China" brand, which originated from its culture. This reflects Hodge and Louie's [18] assessment of the global access to knowledge on China, its language and culture: "We want knowledge about China to circulate as freely and as widely as possible." People's willingness to learn more about China is encouraging the Chinese government to invest more into a host of practices such as the spread of Chinese language and culture via Confucius institutes, and the recruitment of international students through bilateral agreements, student exchange programs, education exhibitions and international scientific and technological collaborations, etc. Higher education as a form of statecraft or foreign policy is a tool to advance national interests, whether related to public diplomacy or specific geopolitical and geo-economic objectives. In recent years, the ministry of education of the People's Republic of China has been active in the internationalization of its higher education. To boost international education collaboration and exchange, highranking government officials of China have met with foreign political leaders, education ministers and diplomats, chancellors and presidents of foreign universities, executives of multinational corporations, heads of international fellowship programs and others. These actions can be considered in terms of education diplomacy. These are part of the Chinese government's initiative to leverage international education initiatives to fulfill policy objectives, including sending Chinese students abroad, expanding foreign enrollment at Chinese institutions, creating foreign branch campuses in China and boosting international research collaboration. Beijing has worked significantly towards internationalizing its higher education. 
China's policy of internationalization of higher education has both hard and soft power effects. According to James Paradise [19], "the hard power effects will be felt as China's economy becomes stronger, its talent pool increases and the quality of its education improves." The soft power effects relating to China's image in the world and an appreciation of Chinese society will be felt as China engages in more collaborative ventures with foreign partners." American political scientist Joseph Nye places education in the high culture domain of soft power, as it is the intangible power resources just like culture, ideology and institutions that shape the 'preferences' of others in contrast to hard power such as military prowess [20]. Higher education is an undeniable instrument of soft power in terms of creating national goodwill, appeal, image and attraction among common people, as well as students of other countries. Nye has described the importance of higher education with reference to the USA during the Cold War, which helped the USA in the cross-border 'diffusion of liberal values and practices' [21]. Similarly, Philip H. Coombs (first Assistant Secretary for Educational and Cultural Affairs under the 1961 legislation) has written about US educational diplomacy, where he has elucidated the increasing governmental scholarships in international education and cultural affairs. He also analyzed the component of education that contributed significantly to the US foreign policy in the post-war period to end the Cold War on favorable terms with the interests and values of American society [22].

In the post-Cold War era, China is also following the footprints of the USA through its "Medium and Long- Term Education Reform and Development Plan (2011-2020)", which added the provision of education aid to developing countries in Beijing's policy of international exchange and cooperation [23]. As China seeks to establish itself as a major player in world affairs, it has realized the critical role of higher education in the projection of soft power. It promotes international exchange and collaboration in order to expand its global influence and to formalize the benefits of its rich heritage and culture by establishing Confucius Institutes (CIs), which are centers for language study linked with universities around the world. As Rui Yang [24], pointed out, "the network of such institutes is a significant tool China has used to expand its international influence and promote its model of governance via the promotion of Chinese language and culture." This move is arguably China's most well-planned soft power policy.

The Chinese language is the immediate way to access its culture and people. After the establishment of the People's Republic of China in 1949, Putonghua (the common language), a form of Mandarin, was legitimized as the country's official language [17]. As an official language, Mandarin has been credited as the language spoken by the greatest number of people in the world (approx. 650 million) [25]. Hence, the government of China started offering Chinese as a foreign language (CFL) courses to citizens of other nations. CFL education began to support China's foreign diplomacy and create international contacts in the 1950s and 1960s, mostly with socialist countries and the Third World, such as Vietnam and several African countries [17]. In 1965, Beijing Languages University was established as the first university that aimed to teach Chinese to overseas students, and now many Chinese universities are offering CFL programs to foreign students. In August 1985, the first conference of CFL teaching was held in Beijing, which is now a worldwide annual event. In the same year, the Ministry of Education first introduced the CFL degree courses at masters and doctoral level in four major universities, namely Beijing Languages University, Beijing Foreign Languages University, Shanghai Foreign Languages University and Huazhong Teachers University. In 1987, the Beijing-based office of the Chinese language council international (involving 11 ministries of the Central Government) was established, known as Hanban, to teach Chinese as a foreign language [17]. Hanban was founded by the government of China to specialize in the policy and practice of developing Chinese as a foreign language in response to market demand, including the preparation and administration of the Hanyu Shuiping Kaoshi (HSK), or Chinese Proficiency Examination, for foreigners. 
Moreover, Hanban promotes cultural exchanges and tours and provides support networks for Chinese teachers and students, as well as a comprehensive range of language teaching and learning resources. As an important part of CFL infrastructure and schemes in policy and practice, the Chinese Language Bridge, which hosted a Chinese language competence competition for university students worldwide, was established in 2002. In recent years, Hanban has promoted joint-venture language centers abroad, the Confucius Institutes (named after one of the most renowned Chinese thinkers, Confucius). This plays a significant role in creating and overseeing CIs.

China's policy of internationalization of its higher education also contributed significantly to its soft power. China's "reform and opening up" period of 1978 can be marked as the starting point of this policy [18]. In 1983, Deng Xiaoping put forward "three orientations," namely that education must be oriented to modernization, the world, and the future. Since then, China has embarked on the road of internationalization of its education system. In 1993, the "Education Reform and Development Outline in China" recommended that it should further expand the scale of opening-up and reforming education, strengthening world communication and cooperation and borrowing management experience from other countries [26]. In 2001, China joined the World Trade Organization. It imposed obligations on Beijing in the area of "Educational Services", one of the sectors in the WTO's classification system for services to which China agreed [18]. According to the "GATS (General Agreement on Trade in Services)" under WTO, education service is one of the key service trades, and its three policies are no prejudice, market opening and fair competition regulations, which state that all participating countries have the right to compete in the education service market. According to Li Mei [27], since China's promise for education service is partial, higher education must be more open, allowing for the faster internationalization of higher education. In the reform period (during the 1980s and 1990s), however, the government strictly regulated teacher exchanges, foreign student enrollments and all other forms of engagement with foreign institutions, requiring government clearance. Since 2000, however, China's socioeconomic progress has encouraged the Chinese government to grant institutions more autonomy, while also speeding up the internationalization process [26]. Chinese universities are now embarking on a full-fledged internationalization initiative, which includes implementing exchange programs, admitting overseas students, offering English-taught courses, building joint research and degree programs and establishing an educational institution in foreign countries.

The government of China has been dedicatedly working on establishing CIs in collaboration with national educational institutes of other countries, with the aim to popularize Chinese culture among foreigners. The first CI was established on a pilot project basis in Tashkent (capital city of Uzbekistan) on 15 June 2004. Later, the world's first fully-fledged Confucius Institute was opened in Seoul, South Korea, on 21 November 2004 [28]. CIs are managed directly through its headquarters in China, which itself is directly subsidiary to Hanban. By the end of 2009, the initial target of 100 CIs was quickly expanded to over 330. As of 2019, there are 530 Confucius Institutes in dozens of countries across six continents [29]. By 2010, the Ministry of Education anticipates that 100 million people throughout the world will have learned Chinese, and the program is fast expanding to keep up. Furthermore, Hanban aims to establish 1,000 Confucius Institutes by 2020 [30]. China's 2012 official document, the "Plan for study in China" also envisioned enhancing the attractiveness of China through educational offerings [31]. The contents of attractiveness towards Chinese culture are clearly stated in the website of the Chinese Ministry of Education, which includes the elements of its traditional values such as harmony, righteousness, benevolence, wisdom, courtesy, loyalty and honesty; food culture; and arts and literature like music, dance, poetry and painting [32]. Apart from this, regarding the cultural experiences of international students, the website of the Chinese Ministry of Education states that it aims to 'encourage foreign students to experience the profound yet interesting Chinese culture and understand the huge achievements China has made [31]. Hence, it can be said that education serves as a soft power resource for China to achieve certain foreign 
policy goals, such as strengthening 'mutual understanding and friendship between the Chinese people and people from all over the world' [33]; generating 'a large number of graduates (international students) who understand China and contribute to connecting China to the rest of the world'; expanding 'international influence'; and promoting 'its model of governance' [23]. China has so far established an educational partnership with approx. 188 countries and regions, and is also carrying out educational cooperation and exchanges with more than 45 international organizations [34]. More than 170 nations offer Chinese language classes and programs, and the number of persons learning and utilizing Mandarin has surpassed 100 million worldwide [33].

Chinese Communist Party general secretary Xi Jinping has a grand vision of the "rejuvenation of the Chinese nation." He identified the role of Confucius Institutes as a resource of soft power, and stated in 2014 that its prominent objective is to "give a good Chinese narrative," as the Chinese government spends about $\$ 10$ billion a year on these soft power initiatives [35]. China is determined to create a brand name for its educational institutions, and make itself a globally attractive educational destination for foreign students. Now, China's Belt and Road Initiative (BRI) has been emerging as a powerful vehicle to extend spheres of influence of China's higher education program and its policy of internationalizing education. Under its BRI project, Beijing is offering special scholarships to students from BRI-member countries. This nexus between higher education and the BRI is sometimes referred to as the "Educational Silk Road" [34]. In 2016, the Chinese Ministry of Education released the BRI Education Action Plan to strengthen educational connectivity between China and BRI countries, and put forward three goals: the promotion of people-to-people ties through China's language, culture and policies; the cultivation of much- needed talent for the BRI; and achieving common development of education along the BRI route to build an 'integrated educational community' [36].

China is now Asia's most popular destination for foreign students, who numbered 492,185 in 2018, with students from BRI countries accounting for nearly 65 percent [37]. In 140 countries and regions around the world, there are 512 Confucius Institutes and 1074 Confucius Classrooms, in which 135 Confucius Institutes and 129 Confucius Classrooms are in 51 countries along the Belt and Road [31]. Chinese leadership hopes that BRI scholarships would help international students become more aware of and accept China's foreign policy. In order to support the Belt and Road Initiative, Renmin University of China (RUC) established the Silk Road School in 2018 after several years of planning, leveraging RUC's educational platform, international operational experience and high level think-tank resources to cultivate future elite leaders for countries along the BRI who have a passion for Chinese culture and understand the path of Chinese development [38]. Undoubtedly, setting "rules and norms" and altering different regions' choices in constructing educational collaboration mechanisms clearly indicate that Nye's definition of soft power- "the ability to shape others' preferences"-is at work in China's massive BRI project, where education plays a prominent role. By this means, China is cultivating its interests in one of the BRI member countries in its immediate neighborhood of Nepal.

\subsection{Nepal's Geopolitical Significance for CHINA}

China's engagement with Nepal is highly motivated by its various geopolitical objectives. Firstly, the "One China" policy has a significant impact on China's relationship with Nepal. This refers to China's own sovereignty and territorial claims, which principally revolve around denying the official recognition of Taiwan and claiming Tibet-the Tibetan Autonomous Region (TAR)—as an important part of the country [39]. Nepal has served as a safe haven for Tibetans fleeing Beijing's rule, as well as a transit route for Tibetan refugees seeking asylum in India and the West. Beijing's relations with Nepal are largely based on an interest that the latter should not become a breeding ground for 'anti-China' activities. Therefore, the primary objective of China in Nepal has been to ensure Kathmandu's recognition of the "One China policy", as well as its cooperation in suppressing Tibetan activists [40]. Secondly, economic motivations play a significant role in Beijing's 
foreign policy, including its expanded engagement in Nepal, as the domestic legitimacy of the Communist Party of China is mainly based on maintaining the country's high rate of growth.

Therefore, improving its economic relations with Kathmandu can potentially enable China to use Nepal as a transit country for trade with the rest of South Asia. Additionally, Nepal has a strategic significance for connectivity through infrastructure under the BRI project for China. China's growing engagement in Nepal can therefore be seen to be motivated on the economic front. Thirdly, China and India are the world's two most populous countries with the fastest-growing economies. There has been a "persistent mutual trust deficit" in relations between these two emerging nations [41]. With China's rise, Nepal's position has grown more strategically important. Because of its location, "it can be seen as a prize to be captured, and could become the locus of geopolitical competition between an expanding China and a defensive India" [38]. India's predominance in South Asia is a matter of concern for China, and being a rising superpower, Beijing is wary of the strong power in its neighborhood. Therefore, countering India's influence is one of China's major goals in Nepal. China is making a strong strategic foothold in Nepal. It is investing heavily in Nepal's economic, political and strategic sectors, which India traditionally dominated. Now, only cultural power is left in India's account vis-à-vis Nepal, which China is trying to replace with its soft power, where education is playing a prominent role.

\section{Discussion}

Nepal's geopolitical and geostrategic location entices China to counter its arm rival India's traditional predominance in the South Asian region. Therefore, China is deepening its strategic foothold in Nepal through cooperation in various spheres, including investment, trade, infrastructure development and higher education. Beijing's engagement in Nepal illuminates the linkages between soft power and higher education. Sino-Nepal cooperation in the higher education sector can be considered Beijing's strategic effort to deepen its academic, cultural and economic influence in Nepal. China is relying on a three-pronged strategy to increase Nepalese recruitment: intensive marketing through exhibitions and delegation visits, including the use of various mediums and channels; substantial scholarships; and the relatively low cost of studying in China.

\subsection{Exhibitions Held by China}

Since China opened up its education sector, it has been organizing exhibitions in various countries, including Nepal. In 2003, the China Education Exhibition was organized in Nepal by the China Scholarship Council, which functions under the Chinese Ministry of Education. This exhibition had drawn approximately 2500 attendees from Nepal, the majority of whom were high school and university students [42]. The objective of the event was to "introduce [the] Chinese higher education system and higher education institutions" [43], with participation from China's 30 higher education institutions, including Tsinghua and Beijing universities, and included comprehensive, scientific, and technical, normal and medical educational institutions. Apart from recent education fairs organized by commercial consultancies, the China Scholarship Council has held such exhibitions in Kathmandu every year since then [36]. These exhibitions are being held and supported by the Arniko Society, an alumni association of scholars and experts who have studied from China and are engaged in various government and non-governmental organizations all over Nepal [44]. According to Dr. Harish Chandra Shah (the former chairman of Arniko Society), "The focus of this exhibition is to inform Nepalese youths that China is one of the best options of higher education which is of an international standard" [42]. In 2013, Fudan alumnus Dr. Kalyan Raj Sharma founded the Nepal China Friendship Forum (NCFF) after returning to Nepal from China. The forum brings together governments, diplomats, academia, the private sector, the media and other relevant organizations and individuals to provide a platform for academic exchange in Chinese and Nepalese literature, medicine, 
social work and other related fields and subjects. Every year since 2015, NCFF has hosted a series of BRI conferences to discuss the benefits of BRI for Nepal and South Asian countries. Furthermore, NCFF is also undertaking projects; namely Saana Haatharu (Little Hands), which aims to promote Chinese culture and additional curriculum activities in secondary school students; and a similar project entitled "Knowing China Better," a collaboration of NCFF and Nepalese schools and universities [45]. In 2017, the China Education Fair was organized in Nepal, which was attended by around 2000 Nepali students aspiring to pursue higher studies at Chinese universities. This fair aimed to provide information and guidance to Nepali students for their subsequent studies in Chinese academic institutions [46]. Furthermore, on 6 December 2018, the Chinese Embassy in Nepal and Nepal- China Cultural and Educational Council organized the fifth gathering of Nepali students who have studied in China. In this event, Nepali Minister for Education, Science and Technology Giriraj Mani Pokharel remarked that "Nepali students who have studied in China are capable manpower who can highly contribute to the country's vision of "Prosperous Nepal, Happy Nepali" [47]. In the same year, the Chinese government launched the "Panda Book Corner" program in collaboration with the Nepal-China Friendship Forum, with the goal of sharing Chinese expertise and experience, promoting the Chinese language among school children, and providing Chinese learning materials to kids. Approximately 5000 books covering Chinese history, economy, culture, festivals, language, music and dictionaries were supplied to schools. Furthermore, the institutions offered a rudimentary Chinese language education to assist students in broadening their horizons of knowledge. On this program, Chinese Ambassador to Nepal Yu Hong opined that "the book corner will provide more knowledge and information about China to Nepali students. She also urged the students to read more books and work as goodwill ambassadors between the two countries in the future." In August 2019, this library support program was expanded to five more Nepalese schools [3]. In the same year, the Chinese Embassy in Nepal held three competitions: the 9th Ambassador Cup Chinese Language Contest, the 8th Chinese Cultural Performance Competition and the 12th Chinese Bridge Proficiency Competition for Foreign Secondary School Students, in which over 750 students from 65 Nepalese schools participated. At this event, the Chinese Ambassador to Nepal Hou Yanqi said that "such educational and cultural contests are a good platform to understand China." She stated that students are the country's future, and expressed the hope that students will serve as ambassadors and contribute to the strengthening of Nepal-China bilateral relations [3]. Similar to this kind of event, a special Chinese cultural show called Splendid Hunan was staged in Nepal to commemorate the 70th anniversary of the founding of the People's Republic of China (PRC) in 2019. More than 600 people from all walks of life in China and Nepal, including teachers and students from Nepal, celebrated the Spring Festival [48].

Apart from that, China's BRI project is also contributing to strengthening the educational cooperation between China and Nepal to a very great extent. During the second Belt and Road Nepal China Education Fair held in Kathmandu, Nepal, on 21 April 2019, Krishna Bahadur Mahara, Speaker of the House of Representatives of Nepal, said that "the China-proposed Belt and Road Initiative (BRI) offers immense development opportunities for Nepal and many other countries." With regard to education in particular, Mahara said "Chinese engineering education is regarded as one of the best in the world. Nepal can gain huge benefits from the progress and development achieved by China in the technical education sector" [49]. The event attracted more than a half-dozen Chinese universities, including Beijing Normal University, Shandong University, Qufu Normal University and Zhejiang Normal University, among others. In addition, the event will include distinct educational cooperation interaction events between Chinese and Nepalese institutions, colleges, academics and students.

In its drive to boost Nepalese students' enrolment in Chinese institutions, the CCP has been organizing and continuously organizing various exhibitions in Nepal. Additionally, the government of China has been providing various scholarships and exchange opportu- 
nities to Nepali students and establishing educational institutions in order to make China a more desirable destination for pursuing further education.

\subsection{Education Institutes Established by China}

The first educational institute, Confucius Institute (CI), was established at Kathmandu University in 2007, with an objective to teach the Chinese language and culture in Nepal; it is a joint collaboration of China's Hebei University of Economics and Business and Nepal's Kathmandu University. Vice-Chancellor of Kathmandu University (KCU) [50]. Suresh Rai Sharma highlighted the significance of Confucius in the Asian civilization similarly; Ambassador Yang Houlan of China to Nepal stated that CIKU had built a bridge of language, culture and friendship between the two nations' peoples. Until 2012, the CIKU course has benefited more than 4000 Nepali students at various levels [49]. On numerous issues concerning China, CIKU seeks to provide a platform for exchanging ideas between Chinese and Nepali Scholars. One of these issues is the "authoritative image of China" among foreigners. Therefore, CI promotes more modern Chinese culture and concerns to help students understand that China and the Chinese people are good, normal everyday people, as opposed to the unfavorable portrayals of China in the Western media [51].

Moreover, the oldest and prestigious Tribhuvan University of Nepal has signed a Memorandum of Understanding (MOU) with 18 Chinese universities covering different fields, like civil engineering, medicine, business and economics, etc. [52]. Recently, in 2018, Tribhuvan University (TU) introduced a completely new aeronautics and astronautics engineering program at the universities for the first time, in cooperation with China's Nanjing University [51]. In the same year, Tribhuvan University and East China University of Technology (ECUT) signed an agreement to establish the Confucius Institute at the central office of Tribhuvan University. Stakeholders speaking at a gathering held at TU on this occasion said the center's establishment would assist Nepal and China deepen their bilateral relations [53].

Similarly, the China Cultural Center (CCC) in Nepal was founded based on a MoU signed between the two nations in Kathmandu on 1 November 2012, with the objective of augmenting the cultural ties between the two countries [54]. Since its establishment in 2015, the center has hosted dozens of events promoting Chinese culture, ranging from a Tianjin Symphony Orchestra New Year concert to courses on conversational Mandarin and traditional Chinese medicine [55]. Moreover, a non-government friendship organization of Nepal, the China Study Center (CSC), established in 1999 by 12 Nepali intellectuals to focus specifically on China affairs and collaborative neighborly relations between Nepal and China [56]. In 2008, a high-level Chinese delegation met with CSC officials for the first time in Nepal, where the CSC and the China Association for International Friendly Contact signed a memorandum of understanding (CAIFC) [57]. Since then, China has established around 30 China Study Centers in Nepal [58]. China is conducting many social and cultural activities in Nepal through study centers, and it also teaches Mandarin to Nepalese youngsters on a large scale. According to sources, many of these study centers have also been built near the India-Nepal border [59]. In 2017, after the destruction caused by the earthquake in Nepal, "Suning-Yuba Sahabhagita School" was established by the donation and support provided by China [60]. Hence, the Universities of Nepal have collaborated with Chinese universities and educational institutes established by China and Nepal, enhancing and strengthening the relationship between the two countries, paving the way for future collaboration in the education sector and enhancing people-to-people contact.

\subsection{Educational Exchange and Scholarship Programs}

In a bid to promote people-to-people relations, China and Nepal signed a Memorandum of Understanding on Cultural Cooperation 1999 and on the Youth Exchange in 2009. Since then, both countries have been executing youth exchange programs through scholarships / fellowships provided by the Government of China. It provides scholarships every year not exceeding a total of 100 Nepalese students studying in China [61]. These 
scholarships are provided to Nepalese students to study for bachelors, masters and doctoral degrees at Chinese universities in various faculties, including medicine, business, engineering and communication, and most importantly the Chinese language. Furthermore, in Gandaki and Hainan, Nepal and China committed to develop and promote tourism, trade, energy, culture and technical and vocational education. Hainan Vocational and Technical College would grant full scholarships to 20 Nepali students as part of the arrangement [59]. Furthermore, for the academic year 2019-2020, approximately 100 Nepali students have been awarded Chinese government scholarships to pursue various degrees at Chinese universities [62]. Apart from that, China organized various courses for Nepali people. One of its kinds is the "Chinese Language Training Course for Nepali Tourism Professionals" organized by the Embassy of China in Nepal, held at the Nepal Tourism Board. On the occasion of its 2nd Graduation Ceremony (2018), Ambassador Yu Hong highlighted new cooperation between the two countries in political, economic and people-to-people and cultural exchanges. She also encouraged the trainees to continue their study of Chinese, understand Chinese culture and serve as a bridge in promoting mutual understanding and friendship of two countries [60]. So far, 120 Nepalese tourism professionals have completed a six-month Chinese language course, with 40 of them graduating in 2016, 2017 and 2018 [60].

Besides, in order to lucrate government officials of Nepal, China offers a record number of training programs and scholarships to civil servants of Nepal. In the previous 15 years, the scholarships provided by China to Nepali civil servants have increased exponentially, totaling more than 850 for the 2019-20 academic years alone. On this massive increase in scholarships by the Chinese government, Yadav Koirala, secretary at the Ministry of General Administration and Federal Affairs, commented that "they do not have a fixed quota, as they keep increasing it" [63]. Koirala himself had spent nearly a year in China, where he had finished a national defense course. According to a joint communiqué, China agreed to provide Nepal with around 400 training opportunities in human resources development, as well as more government scholarships [62].

Not only this, but China has also had a significant influence over Nepalese high offices; for the only one of its kind in 2017, Vice-President Mr. Liu Shengxue paid official calls on the Nepal Ministry of Education and Nepal Medical Council. The delegation proposed introducing University of South China (USC) initiatives to build collaborative programs with Nepal educational institutions establish the Confucius Academy in Nepal and broaden students' recruitment channels. In response, on behalf of the Nepal Ministry of Education, joint secretary and spokesman Mr. Hari Prasad Lamsal expressed his appreciation and willingness to support USC's international education exchange and cooperative moves in Nepal, and offered the government's help if necessary. Similarly, Nepal Medical Council Registrar Dr. Dilip Sharma also warmly welcomed the delegation and inquired details about the medical education mechanisms in USC, informed the requirements of higher medical education acknowledged by the NMC, and expressed his willingness to recommend more and more Nepali students to study in China. The point to be noted here is that Nepal Medical Council is a legislative institution of the Federal Republic of Nepal, and any Nepali student who wants to study medicine in any foreign university must receive approval from this institution; otherwise, when they graduate and go back to Nepal, they will not be able to take part in the Doctor's Licensing Examination. Similarly, the Ministry of Education is the apex body of Nepal responsible for formulating the country's education policy, and grants 'No Objection Certificates' to Nepalese citizens before they can study abroad. Therefore, the praise the Chinese delegation received from these institutions shows its goodwill in the eyes of the government bodies of Nepal [64].

Aside from these chances for governmental personnel, China offers a wide range of long- and short-term courses for journalists, security officials, students and political party leaders [63]. Furthermore, since the BRI agreement, Nepal and China have seen many cultural exchange programs as the scholarship quota for Nepal has risen. In Nepal, the China Cultural Centre was established, and numerous cultural teams have made 
bilateral trips, as well as more people choosing to study the Chinese language [65]. In 2018, the Nepalese Youth "Discovering Sichuan" Autumn Camp was held in China. In this event, Nepalese students received the chance to visit and live in Chengdu city of China, where they got first-hand experience of Chinese culture, historical monuments, histories, traditions and interaction with Chinese people [66]. Recently (2019), following a proposal by the Chinese government to subsidize the salary of Mandarian teachers in Nepal, numerous private schools in the Himalayan country have made it mandatory for students to learn the language. In addition, the Communist Party of Nepal (CPN) has organized a virtual conference with the Communist Party of China (CPC) to discuss and share their experiences on running the party and government [67]. The announcement came at a time when Chinese investment in Nepal is on the rise, due in part to Beijing's ambitious Belt and Road initiative [68]. Noting that youth exchange programs are an important aspect of China's Belt and Road Initiative, the role of youths who can work as a bridge between the two countries cannot be ignored.

\subsection{Limitations}

This review paper has certain limitations due to the non-availability of statistical data and dependency on secondary resources. In particular, statistical data regarding China's investment in Nepal's education sector is not available; therefore, the most authentic and reliable available sources that show the indirect investment of China in Nepal's education sector in the form of cooperation/collaboration have been used.

\section{Conclusions}

Within the past decades, the policy of internationalization of higher education in China has contributed to the transformation of Chinese foreign policy into an educationdriven policy. As China strives to establish itself as a major actor in international affairs, it has recognized the vital role of higher education in soft power projection. By boosting initiatives such as education collaboration and exchange, official visits of education ministers and diplomats, expanding foreign enrollment at Chinese institutions, creating foreign branch campuses in China, advancing international research collaboration and a range of scholarship opportunities, China is leveraging international education to fulfill its policy objectives. Higher education is an instrument of cultural soft power, helping Beijing creates national goodwill, appeal, image and attraction among common people and students of other countries.

To fulfill its geopolitical objectives in South Asia and bring Nepal closer to China, Beijing utilizes the channel of higher education through its investment in Nepal's education sector. From making Mandarin compulsory in schools to offering a range of scholarships with the establishment of various institutions, Beijing is making a range of efforts to win the hearts and minds of common people, as well as the leadership of Nepal. Confucius Institutes have been actively engaging in providing a "positive Chinese narrative" to the Nepali people. A brand name of Chinese educational institutions has been making China an attractive destination for Nepali students to pursue higher education. These aspects of Chinese soft power in Nepal have changed the cultural dynamics in Nepal, which is traditionally in favor of India.

The statements and recognition of political and diplomatic leaders of Nepal regarding Beijing's educational aid show the success of China's public diplomacy and soft power. Observing the role of education in China's Nepal policy as a part of a much larger process of cultural integration between the Chinese and the Nepalese, China gained significant goodwill in the country. Furthermore, learning Mandarin in school was viewed as favorable among Nepali students, as it paved their way to China to pursue higher education. Not only this, but China's economic prosperity and development is also tempting Nepali students to study in China. Hence, China-Nepal educational relations are, in fact, working both ways. On one side, it is helping China to fulfill its geopolitical ambitions in Nepal, while on the other it is assisting Nepali students in advancing their career opportunities. 
China's "Education Silk Road" under the BRI project is also taking their education relations to new heights. Hence, it is notable that China's investment in Nepal's higher education is serving as a bridge between their bilateral relations. However, this growing clout of China might pose some threat to the indigenous culture and language of Nepal. In the long run, it might change the cultural landscape of Nepal, as well as dampen its relations with other countries. Therefore, Kathmandu should remain cautious while taking economic favor from Beijing, particularly in the education sector. Notably, the importance of education cooperation in China-Nepal relations brings education to the forefront in international foreign policy discourse.

Author Contributions: Conceptualization, B.S. and V.K.C.; methodology, B.S. and V.K.C.; literature review, P.G. and B.S.; initial draft preparation, P.G. and B.S.; manuscript revision, V.K.C., editing and finalization, V.K.C. All authors have read and agreed to the published version of the manuscript.

Funding: This research received no internal or external funding.

Institutional Review Board Statement: Not applicable.

Informed Consent Statement: Not applicable.

Data Availability Statement: The data presented in this study are available on request from the corresponding author.

Conflicts of Interest: The authors declare no conflict of interest.

\section{References}

1. Kalyan Raj Sharma: Contributor to China-Nepal Friendship. Fudan University. 2021. Available online: https://www.fudan.edu. cn/en/2021/0415/c344a108517/page.htm (accessed on 21 June 2021).

2. Nepal Schools Make Chinese Language Compulsory. Deccan Herald. 15 June 2019. Available online: https://www.deccanherald. com/international/nepal-schools-make-chinese-language-compulsory-740484.html (accessed on 25 May 2021).

3. China Tops FDI Pledges to Nepal Three Years in a Row. Xinhua English.news.cn. 2019. Available online: http:/ / www.xinhuanet. com/english/2018-08/01/___137360898.htm (accessed on 8 July 2021).

4. Chinese FDI Pledges to Nepal Nearly Double in FY 2019-2020 Despite Pandemic. Xinhua I English.news.cn. 2020. Available online: http:/ / www.xinhuanet.com/english/2020-09/09/c_139354989.htm (accessed on 8 July 2021).

5. Nepal's Delicate Balancing Act between China and India-Asia- An In-Depth Look at News from Across the Continent. DW. 3 March 2020. Available online: https://www.dw.com/en/nepals-delicate-balancing-act-between-china-and-india/a-52693835 (accessed on 21 June 2021).

6. Pandey, A. Economics and Influence: Chinese Investment in Nepal. Stimson Center. 12 November 2020. Available online: https:/ / www.stimson.org/2020/economics-and-influence-chinese-investment-in-nepal/ (accessed on 5 July 2021).

7. Acharya, A. Power shift or paradigm shift? China's rise and Asia's emerging security order. Int. Stud. Q. 2014, 58, 158-173. [CrossRef]

8. Holslag, J. Chapter Two: Engaging the Hegemon. Adelphi Ser. 2010, 50, 29-74. [CrossRef]

9. Kai, J. Rising China in a Changing World: Power Transitions and Global Leadership; Springer: Berlin/Heidelberg, Germany, 2016.

10. Stiglitz, J.E. The Chinese Century. 4 December 2014. Available online: https://www.vanityfair.com/news/2015/01/chinaworlds-largest-economy (accessed on 25 September 2020).

11. Ojha, H. The India-Nepal Crisis. 27 November 2015. Available online: https://thediplomat.com/2015/11/the-india-nepal-crisis/ (accessed on 8 July 2021).

12. Nepal Redraws Political Map by Incorporating 3 Indian Areas. Deccan Herald. 18 June 2020. Available online: https: / www.deccanherald.com/international/world-news-politics/nepal-redraws-political-map-by-incorporating-3-indian-areas-851119.html (accessed on 21 June 2021).

13. Krishnan, A. China is Largest FDI Source for Nepal, overtakes India. The Hindu. 26 January 2014. Available online: https:/ /www. thehindu.com/news/international/world/china-is-largest-fdi-source-for-nepal-overtakes-india/article5618081.ece (accessed on 21 June 2021).

14. 160 Nepali Students to Study in China under Gov't Scholarship-Xinhua I English.news.cn. 28 August 2018. Available online: http:/ / www.xinhuanet.com/english/2018-08/28/c_137423413.htm (accessed on 21 June 2021).

15. Lanteigne, M. Chinese Foreign Policy: An Introduction; Routledge: Abingdon, UK, 2019.

16. Kurlantzick, J. Charm Offensive: How China's Soft Power Is Transforming the World; Yale University Press: London, UK, 2007.

17. Nye, J.S. The Rise of China's Soft Power. WSJ. 29 December 2005. Available online: https://www.wsj.com/articles/SB113580867 242333272 (accessed on 21 June 2021).

18. Zhao, H.; Huang, J. China's policy of Chinese as a foreign language and the use of overseas Confucius Institutes. Educ. Res. Policy Pract. 2010, 9, 127-142. [CrossRef] 
19. Paradise, J. International Education: Diplomacy in China. Brown J. World Aff. 2012, 19, 195-205.

20. Nye, J.S. The Changing Nature of World Power. Political Sci. Q. 1990, 105, 177-192. [CrossRef]

21. Atkinson, C. Does Soft Power Matter? A Comparative Analysis of Student Exchange Programs 1980-2006. Foreign Policy Anal. 2010, 6, 1-22. [CrossRef]

22. Coombs, P.H. The Fourth Dimension of Foreign Policy: Educational and Cultural Affairs; Council on Foreign Relations; Harper \& Row: Manhattan, NY, USA, 1964.

23. China-Education-Plan-2010-2020.pdf. Outline of China's National Plan for Medium and Long-term Education Reform and Development. 2010, pp. 35-36. Available online: http:/ / ncee.org/wp-content/uploads/2016/12/Sha-non-AV-5-China-EducationPlan-2010-2020.pdf (accessed on 21 June 2021).

24. Yang, R. Soft Power and Higher Education: An examination of China's Confucius Institutes; Taylor \& Francis Group: 2014. Available online: https://www.taylorfrancis.com/chapters/edit/10.4324/9781315872681-11/soft-power-higher-educationexamination-china-confucius-institutes-rui-yang (accessed on 21 June 2021).

25. Crystal, D. English As a Global Language; Ernst Klett Sprachen: Stuttgart, Germany, 2003.

26. Chen, D. Internationalization of Higher Education in China and Its Development Direction. High. Educ. Stud. 2011, 1, 79-83. [CrossRef]

27. Li, F. The internationalization of higher education in China: The role of government. J. Int. Educ. Res. (JIER) 2016, 12, 47-52. [CrossRef]

28. Hong, Z. Confucius School, a National Strategy for Chinese Language Teaching. 2005. Available online: https://suyifa.dev.test. zazhipuzi.com/4242 (accessed on 21 June 2021).

29. Wolf Warriors. Let's Know Things. 2021. Available online: https:/ / letsknowthings.com/episode262/ (accessed on 21 June 2021).

30. Confucius Institutes Expanding Rapidly to Meet Demand for Chinese Language Skills. 14 July 2014. ICEF Monitor-Market Intelligence for International Student Recruitment. Available online: https: / / monitor.icef.com/2014/07/confucius-institutesexpanding-rapidly-to-meet-demand-for-chinese-language-skills / (accessed on 28 June 2021).

31. China Scholarship Council-Chinese Government Scholarships. Study In China. 2021. Available online: https://www. studyinchina.com.my/web/page/csc-chinese-government-scholarship/ (accessed on 21 June 2021).

32. Ministry of Education of the People's Republic of China. My Chinese New Year Experience. 2018. Available online: http: / / en.moe.gov.cn/ (accessed on 21 June 2021).

33. Notice to International Students Studying in China under Chinese Government Scholarship Program. Hunan University. Available online: http:/ / www-en.hnu.edu.cn/info/1040/2263.htm (accessed on 21 June 2021).

34. Ministry of Education of the People's Republic of China. Educational Opening Up to Provide Services for the Belt and Road. 26 June 2018. Available online: http://en.moe.gov.cn/Specials/Review/Facts_2147443481/201806/t20180626_341024.html (accessed on 21 June 2021).

35. D'Hooghe, I. 2 China's BRI and International Cooperation in Higher Education and Research. In Global Perspectives on China's Belt and Road Initiative; Amsterdam University Press: Amsterdam, The Netherlands, 2021; pp. 35-58.

36. Education Action Plan for the Belt and Road Initiative. Xinhua Silk Road. 16 June 2020. Available online: https:/ / en.imsilkroad. $\mathrm{com} / \mathrm{p} / 314241 . h \mathrm{~m} l$ (accessed on 21 June 2021).

37. Jain, R. China's Strategic Foray into Higher Education: Goals and Motivations vis-à-vis Nepal. Dipl. Statecraft 2020, 31, 534-556. [CrossRef]

38. Ildikó, N. Admissions-Silk Road School at Renmin University of China (World). 23 May 2018. Available online: https: / / admissions.sze.hu/silk-road-school-at-renmin-university-of-china (accessed on 21 June 2021).

39. Attree, L. China and Conflict-Affected States: Between Principle and Pragmatism. Sudan and South Sudan. Lond. Saferworld. 2012, 1, 63-83. Available online: https:/ / www.ecosonline.org/reports/2012/Saferworld_China_and_conflict-affected_states.pdf (accessed on 15 June 2021).

40. Dabhade, M.; Pant, H.V. Coping with challenges to sovereignty: Sino-Indian rivalry and Nepal's foreign policy. Contemp. South Asia 2004, 13, 157-169. [CrossRef]

41. Singh, S. Paradigm shift in India-China relations: From bilateralism to multilateralism. J. Int. Aff. 2011, 64, 155-168.

42. China Education Exhibition Held in Nepal. People's Daily Online. 9 August 2009. Available online: http:/ / en.people.cn/90001/90 776/90883/6722512.html (accessed on 21 June 2021).

43. Nepal-China Education Exchange Forum Held in Nepal. Global Times. 5 May 2010. Available online: https://www.globaltimes. cn/content/532080.shtml (accessed on 21 June 2021).

44. Who We Are: Arniko Society. Available online: https://www.arnikosociety.com.np/about.php (accessed on 21 June 2021).

45. Dr. Sharma bags Silk Road Friendship Award. 22 December 2020. Available online: https://english.nepalpage.com/2020/12/drsharma-bags-silk-road-friendship-award/ (accessed on 21 June 2021).

46. China Education Fair Attracts Nepali Students to Study at Chinese Universities-Xinhua I English.news.cn. 10 December 2017. Available online: http:/ / www.xinhuanet.com//english/2017-12/10/c_136815493.htm (accessed on 21 June 2021).

47. Talents Trained in China Contribute Highly to Nepal's Prosperity Goal: Minister. Xinhua English.news.cn. 6 December 2018. Available online: http:/ / www.xinhuanet.com/english/2018-12/06/c_137655259.htm (accessed on 21 June 2021).

48. Chinese Cultural Show Staged in Nepal to Celebrate 70th Anniversary of PRC Founding-Xinhua I English.news.cn. 27 September 2019. Available online: http://www.xinhuanet.com/english/2019-09/27/__138427101.htm (accessed on 21 June 2021). 
49. BRI Offers Development Opportunities for Many Countries: Nepal's Parliament Speaker. People's Daily Online. 22 April 2019. Available online: http:/ / en.people.cn/n3/2019/0422/c90000-9570471.html (accessed on 21 June 2021).

50. Confucius Institute Celebrates 5th Anniversary in Nepal. Global Times. 17 July 2012. Available online: https://www.globaltimes. $\mathrm{cn} /$ content/721534.shtml (accessed on 21 June 2021).

51. Confucius Institute at Kathmandu University. Available online: http:/ / ci.ku.edu.np/index.php?go=vol10-1 (accessed on 21 June 2021).

52. Nepal to Introduce Aeronautics Engineering in Cooperation with Chinese University. Xinhua I English.news.cn. 15 January 2018. Available online: http:/ / www.xinhuanet.com/english/2018-01/15/c_136897578.htm (accessed on 21 June 2021).

53. Confucius Institute to Be Set Up at TU-MyRepublica-The New York Times Partner, Latest news of Nepal in English, Latest News Articles. 16 June 2018. Available online: https: / / myrepublica.nagariknetwork.com/news / confucius-institute-to-be-set-up-at-tu/ (accessed on 21 June 2021).

54. China Cultural Center.18 March 2015. Available online: http:/ / en.chinaculture.org/ccc/Nepal.html (accessed on 21 June 2021).

55. Zheng, S. Is Nepal Falling for China's Soft Power Charm Offensive? 8 January 2018. Available online: https://sg.news. yahoo.com/nepal-falling-china-soft-power-033341804.html?guccounter=1\&guce_referrer=aHR0cHM6Ly93d3cuZ29vZ2 xlLmNvbS8\&guce_referrer_sig=AQAAAIdaiSQ3oH4iiflXVQJOPQp3WiistdKauXjVs4OTSVwCYA6A_ef84e77p-1K-daIJxv6 LpQSoxxArxMaQUIJLbI7PrTucBuCzmrs4AJUxyQdHo2NP7Gd9iCiJQyNdjM8PniIpG24dfrzLWJ1ZyPkefOnAdPoQZXgsL4_7 x2iXjnc (accessed on 21 June 2021).

56. China Study Center (CSC). Available online: http:/ / cscnepal.org.np/about.php (accessed on 21 June 2021).

57. Dev Raj. Chinese Checkers. Hindustan Times. 1 May 2013. Available online: https://www.hindustantimes.com/patna/chinesecheckers / story-mCnttFY4TvCShFmdR71WRN.html (accessed on 20 June 2021).

58. Rathore, V. China Open 30 Study Center Near Indian Border in Nepal Side. NewsTrack English 1. 21 August 2020. Available online: https: / english.newstracklive.com/news/china-open-30-study-center-near-indian-border-in-nepal-side-mc23-nu764 -ta272-1114440-1.html (accessed on 21 June 2021).

59. Singh, R. China Opens Study Centres in Nepal to Push Anti-India Agenda. The Daily Guardian. 21 August 2020. Available online: https:/ / thedailyguardian.com/china-opens-study-centres-in-nepal-to-push-anti-india-agenda/ (accessed on 18 June 2021).

60. Sharma, B.P. China-Nepal relations: A cooperative partnership in slow motion. China Q. Int. Strateg. Stud. 2018, 4, 439-455. [CrossRef]

61. Nepal-China Relations-Ministry of Foreign Affairs Nepal MOFA. 2019. Available online: https://mofa.gov.np/nepal-chinarelations / (accessed on 21 June 2021).

62. Over 100 Nepali Students to Study in China under Government Scholarship.Xinhua I English.news.cn. 28 August 2019. Available online: http:/ / www.xinhuanet.com/english/2019-08/28/c_138343188.htm (accessed on 21 June 2021).

63. Giri, A. China Offers a Record Number of Training Programmes and Scholarships to Nepali Civil Servants. 25 June 2019. Available online: https:/ / kathmandupost.com/politics/2019/06/25/china-offers-a-record-number-of-training-programmesand-scholarships-to-nepali-civil-servants (accessed on 21 June 2021).

64. University of South China. Vice-President Paid an Official Call on Nepal Ministry of Education and Medical Council. 29 May 2017. Available online: https:/ / gjxy.usc.edu.cn/info/1009/1118.htm (accessed on 21 June 2021).

65. BRI Is an Opportunity for Nepal to Materialize Its Urge for Development. People's Daily Online. 12 July 2019. Available online: http:/ / en.people.cn/n3/2019/0712/c90000-9596683.html (accessed on 21 June 2021).

66. A Retrospective in Commemoration of the 65th Anniversary of the Establishment of Diplomatic Relations between China and Nepal. Embassy of the People's Republic of China in Nepal. Available online: http:/ / np.chineseembassy.org/eng/Diplomacy/t18028 45.htm (accessed on 21 June 2021).

67. Singh, M.; Behal, S. China's Proxy Battle with India in Nepal. ORF. 3 July 2020. Available online: https://www.orfonline.org/ expert-speak/chinas-proxy-battle-with-india-in-nepal-69016/ (accessed on 21 June 2021).

68. Nepal Schools Make Mandarin Compulsory after China Offers to Pay Teachers' Salaries-Times of India. 15 June 2019. Available online: https:/ / timesofindia.indiatimes.com/world/south-asia/nepal-schools-make-mandarin-compulsory-after-china-offersto-pay-teachers-salaries/articleshow /69799114.cms (accessed on 21 June 2021). 